\title{
Lingual Lipase: an Important Lipase in the Digestion of Dietary Lipids in Cystic Fibrosis?
}

\author{
BO FREDRIKZON ${ }^{(30)}$ AND LARS BLÄCKBERG \\ Departments of Pediatrics and Chemistry, Section on Physiological Chemistry, University of Umea, \\ S-901 87 Umea, Sweden
}

\begin{abstract}
Summary
A convenient lipase assay that discriminates between pancreatic and lingual lipase activities was developed to describe some properties of the triglyceride-hydrolyzing activities of lingual lipase (from von Ebners glands) and pancreatic lipase. Secretion of lingual lipase is stimulated by feeding. Gastric contents collected postyprandially from patients with cystic fibrosis (CF) contained lipase activity which is probably secreted from pharyngeal tissues. Also, duodenal contents from CF patients contained lipase activity with properties very close to those found in gastric contents from CF patients and controls. Apparently, the serous glands responsible for the secretion of lingual lipase is less affected than the exocrine pancrease in this disease.

During fat balance experiments, CF patients utilized around $40 \%$ of the dietary lipids and more than $50 \%$ of milk lipids given as a test meal were hydrolyzed in the duodenum within $2 \mathrm{hr}$.

In these patients with severe pancreatic insufficiency, we suggest that the lingual lipase is responsible for a considerable proportion of triglyceride hydrolysis. This hydrolysis starts in the stomach and continues in duodenum.

\section{Speculation}

Due to pancreatic insufficiency, duodenal contents in cystic fibrosis patients is low in proteolytic enzyme activities and also low in pH. Thus, lingual lipase is not rapidly inactivated, and, furthermore, intraluminal $\mathrm{pH}$ is near the optimum for catalytic activity of the lingual lipase. This lipase is active in the duodenum where it hydrolyzes a considerable amount of dietary triglycerides. We find it quite probable that the lingual lipase in a similar manner is responsible for a substantial hydrolysis also in healthy subjects, especially in the newborn period where postprandial pancreatic lipase activity is comparatively low (10).
\end{abstract}

Dietary lipids are normally hydrolyzed by the action of several enzymes secreted from the pancreas. Most important of these is the pancreatic lipase which readily hydrolyzes dietary triglycerides to monoglycerides and fatty acids $(3,17)$. Pancreatic juice also contains a carboxylester hydrolase activity (8), in this study referred to as esterase, which mainly acts on water-soluble substrates, e.g., $p$-nitrophenyl acetate. In the presence of bile salt, however, it hydrolyzes lipids, e.g., monoglycerides, cholesterol esters, retinol esters. etc. (8). It may, thus, be of significance in the digestion of these compounds.

Patients with cystic fibrosis (CF) almost invariably have exocrine pancreatic insufficiency (6) leading to poor utilization of dietary lipids, and supplementation of exogenous enzyme preparations is often necessary to decrease steatorrhea. The fecal fat excretion may vary greatly during nonsupplementary periods, although lipase activity in duodenal contents from these patients is often low or absent $(18,19)$. This indicates that lipolytic enzymes not dependent on pancreatic functions could play a role in the lipid digestion. A further support for this is a finding by Muller $e t$ al. (20) that a patient with pancreatic lipase deficiency absorbed around $50 \%$ of the dietary triglycerides.

Lipase activity has been found in gastric contents from pre- and full-term infants and in adults $(9,12,15)$. This activity originates, at least to some extent, in pharyngeal tissue $(2,14)$. Recently, Hamosh and Burns (13) showed that in the human the von Ebner glands located in the posterior region of the tongue secrete this lipase, the so-called lingual or pharyngeal lipase. This is in agreement with observations made in the rat and calf $(2,21)$. The properties of this lipase makes it very suitable for action in the stomach. It is very resistant to acid inactivation (9). Its optimal catalytical activity is found in the $\mathrm{pH}$ range of 5.4 to $6.5(2,12)$ which is close to what is prevailing in the stomach after a food intake. The release of lingual lipase is stimulated by feeding (9), which further supports a role in lipid digestion. After mixing with the food in the pharynx, the lipase is swallowed, and in the stomach, it hydrolyzes dietary lipids to partial glycerides and fatty acids. This may be the first step in the fat digestion (12). In view of these known facts, it was of interest to study whether lingual lipase activity is present in gastric and duodenal contents from patients with cystic fibrosis and, if so, if this activity could be of importance for the lipid digestion in these patients.

To test this, we designed a method for discriminating between lingual and pancreatic lipase using their different $\mathrm{pH}$ optima and the inhibition by protein of pancreatic lipase previously demonstrated $(1,4)$

\section{MATERIALS AND METHODS}

\section{CF PATIENTS}

Gastric and/or duodenal contents were collected through an infant feeding tube as described before $(9,10)$ from six patients with cystic fibrosis $(28,29)$. In each case, the diagnosis was based on elevated electrolyte concentrations in at least two sweat tests (sodium $>75$ mmoles $\times 1^{-1}$; chloride $>100$ mmoles $\times 1^{-1}$ ) and in some cases on determinations of fecal chymotrypsin activity which was low or absent. All patients also had varying degree of malabsorption at the time for diagnosis and were treated with pancreatic enzyme preparations. This treatment was discontinued, however, for at least $12 \mathrm{hr}$ before this study was undertaken.

Gastric contents were collected before and about $1 \mathrm{hr}$ after the test meals from four patients: cases J. R. (age, 10 years), S. J. (age, 15 months), and L. N. and T. N. (see Table 1). Duodenal contents were collected 2 to $3 \mathrm{hr}$ after feeding from cases presented in Table 1. All samples of gastric and duodenal contents from $C F$ patients were much more viscous than those obtained from controls. 
Table 1. Clinical and laboratory findings in duodenal contents collected from $C F$ patients and controls

\begin{tabular}{|c|c|c|c|c|c|c|}
\hline \multirow[b]{3}{*}{ Cases } & \multirow[b]{3}{*}{ Age } & \multicolumn{4}{|c|}{ Lipase activity (units/ml) } & \multirow{3}{*}{$\begin{array}{c}\text { Ester- } \\
\text { ase ac- } \\
\text { tivity } \\
\text { (units/ } \\
\text { ml) }\end{array}$} \\
\hline & & \multicolumn{2}{|c|}{ Tributyrin } & \multicolumn{2}{|c|}{ Triolein ${ }^{1}$} & \\
\hline & & pH 5.5 & pH 8.0 & $\mathrm{pH} 6.0$ & $\mathrm{pH} 8.0$ & \\
\hline L. N. & 9 mos. & $4-17$ & $0-2$ & 0.8 & 0.2 & $0-0.1^{2}$ \\
\hline T. F. & $10 \mathrm{yr}$ & n.d. ${ }^{3}$ & n.d. & 2.3 & 0.9 & n.d. \\
\hline N. L. & $10 \mathrm{yr}$ & n.d. & n.d. & 4.0 & 3.2 & $0.1-0.2^{2}$ \\
\hline T. N. & $22 \mathrm{yr}$ & 37 & 6 & 4.3 & 0.8 & 0.1 \\
\hline $\begin{array}{l}\text { Controls } \\
\qquad(N=5)\end{array}$ & $5-11$ mos. & n.d. & $321-1420$ & 1.5 & 168 & $14.2-34.1$ \\
\hline $\begin{array}{l}\text { Controls } \\
\qquad(N=4)\end{array}$ & Adults & n.d. & $331-891$ & $4.9-5.3^{4}$ & $0.9^{4}$ & $10.8-20.0$ \\
\hline
\end{tabular}

${ }^{1}$ Assayed with $8 \mathrm{mM} \mathrm{CaCl} 2$.

${ }^{2}$ Range of four samples.

3 n.d., not determined.

Assayed with $2.8 \%$ albumin.

The test meals given were cow's milk except for case $\mathrm{L}$. N. (pasteurized human milk) and case S. J. (cow's milk-based formula). The fat load in all cases was $1 \mathrm{~g}$ fat per $\mathrm{kg}$ body weight.

\section{CONTROLS}

Samples of gastric contents were collected from four healthy preterm infants and three infants with pyloric stenosis. Gastric contents were collected before and after feeding pasteurized human milk. All bile-stained samples were discarded.

Duodenal contents were collected from five fasting infants during an intestinal biopsy procedure and from four healthy fasting adults. Duodenal contents were collected only after fluoroscopic control of the position of the biopsy capsule or the feeding tube.

\section{LABORATORY PROCEDURES}

Sweat tests were carried out using standard pilocarpine iontophoresis technique. Fecal fat was determined according to van de Kamer et al. (24) on 3 days consecutive stool collections. Lipid composition in duodenal contents was analyzed as described previously (22).

\section{DETERMINATIONS OF ENZYME ACTIVITIES}

Lipase activity was determined against short and/or long chain triglycerides, i.e., tributyrin or triolein. The assay with tributyrin was performed at pH 5.5 or $\mathrm{pH} 8.0$. Details of the assay were as previously described (9).

The method using long-chain triglycerides was essentially that described elsewhere (2), with the following additions and alterations. The buffer was left out in the initial assay mixture. Different buffers, $\mathrm{pH} 3.5$ to 6.0 citrate, $\mathrm{pH} 6.0$ to 7.5 phosphate, $\mathrm{pH} 7.5$ to 9.0 Tris- $\mathrm{HCl}$, and $\mathrm{pH} 9.0$ to 10.5 glycine- $\mathrm{NaOH}$ were added to the individual test tubes to a final concentration of $0.1 \mathrm{M}$. Incubations were carried out either including $2.8 \%$ bovine serum albumin or $8 \mathrm{mM} \mathrm{CaCl}_{2}$.

Resistance to acid inactivation of lipase activity was tested in duodenal contents from $T$. $N$. and from one of the controls as follows. Samples of duodenal contents were incubated in 5 to 10 volumes of $0.15 \mathrm{M} \mathrm{NaCl}$ in $1.0 \mathrm{M}$ citrate-phosphate buffer, $\mathrm{pH}$ 3.0 , for $25 \mathrm{~min}$ at $25^{\circ} \mathrm{C}$. Lipase activities were then determined at pH 5.5 and $\mathrm{pH} 8.0$ using tributyrin as substrate.

Esterase activity was determined against $p$-nitrophenyl acetate essentially as described by Erlanson (7). For further details of assay systems, see previous reports and legends to Table 1 and Figures 1 to 5 .

One enzyme unit is defined as that amount of enzyme that releases $1 \mu$ mole of fatty acid or $1 \mu$ mole of $p$-nitrophenol per min. Units $\times \mathrm{ml}^{-1}$ refers to enzyme activity in $1 \mathrm{ml}$ of enzyme source.

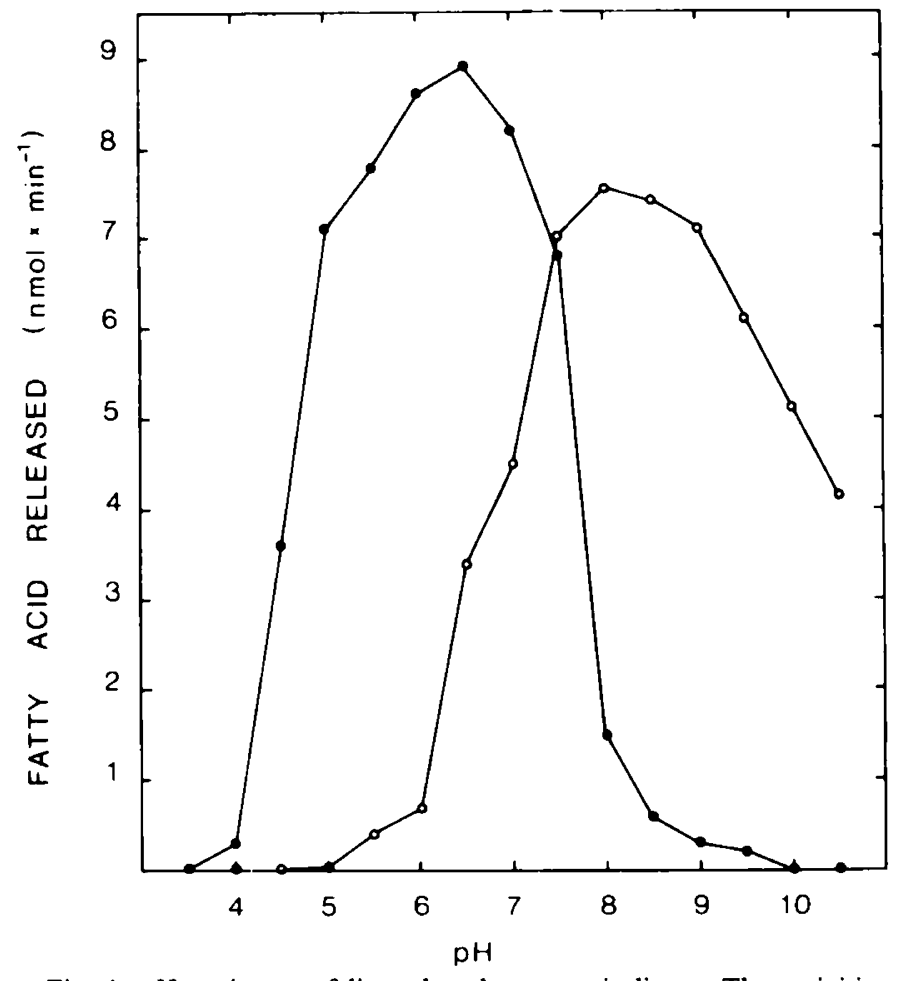

Fig. 1. $\mathrm{pH}$ optimum of lingual and pancreatic lipase. The activities were measured using long-chain triglycerides as substrate. Pancreatic lipase (porcine) is measured with $8 \mathrm{mM} \mathrm{CaCl}_{2}$ in the system $(\mathrm{O})$, lingual lipase (from rat) with $2.8 \%$ bovine serum albumin instead (๑). The amounts of the two enzymes were chosen so that they would give similar rates of hydrolysis.

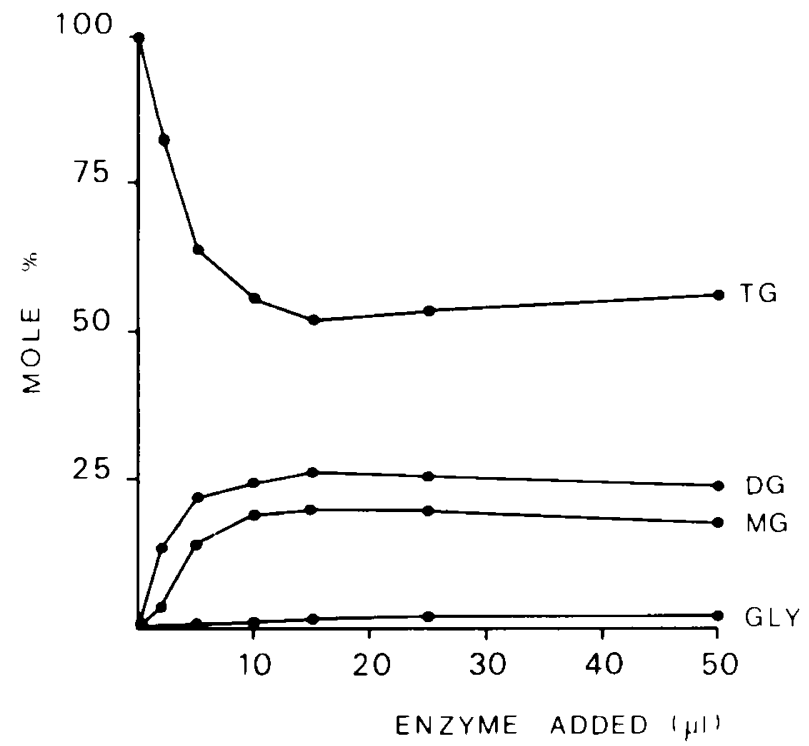

Fig. 2. Composition of reaction products formed during in vitro hydrolysis of emulsified triolein by gastric content from $T$. N. Incubations were performed as described previously (2). $T G$, triglyceride; $D G$, diglyceride; $M G$, monoglyceride; $G L Y$, glycerol.

\section{PREPARATION OF ENZYMES}

Lingual lipase was prepared from rat tongue as previously described (2). Pancreatic lipase was purified from porcine pancreas according to Verger et al. (25) omitting the final ion exchange chromatography. 


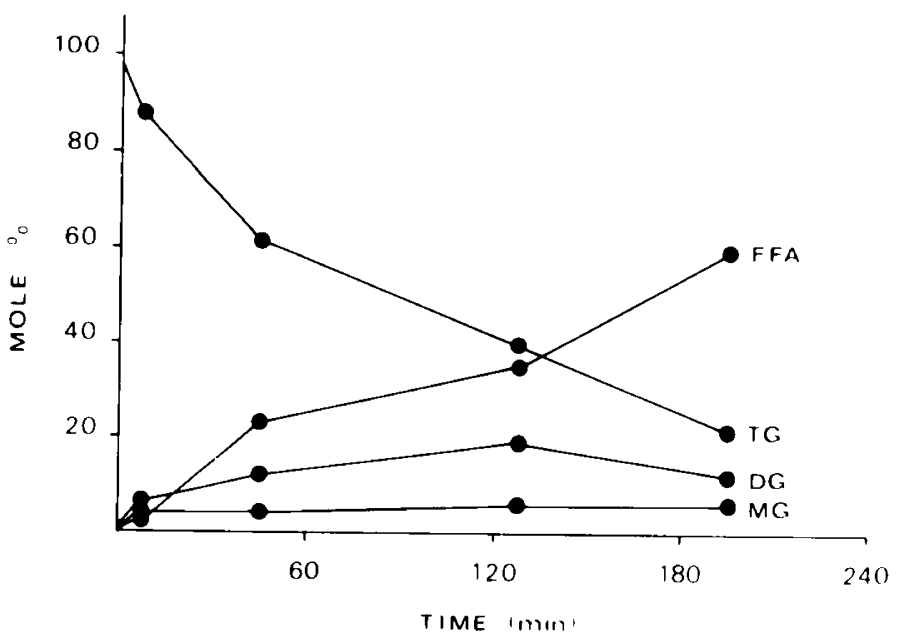

Fig. 3. Lipid composition of duodenal contents collected from L. N. during a test meal of pasteurized human milk. The values are expressed in percentage of total glycerides. $T G$, triglyceride; $D G$, diglyceride; $M G$, monoglyceride; $F F A$, free fatty acids. Separation and quantitation of the partial glycerides was performed as described previously (22).

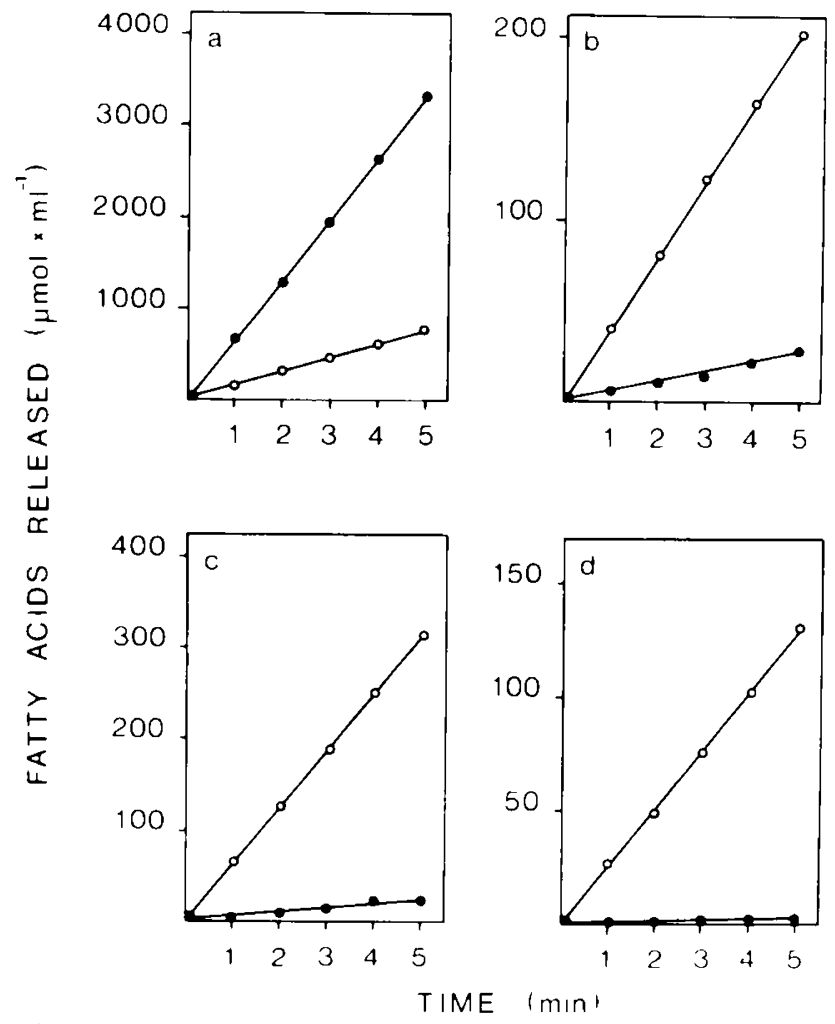

Fig. 4. Hydrolysis of tributyrin by gastric and duodenal contents at $\mathrm{pH}$ $8.0(O)$ and at pH $5.5(\mathrm{O}): a, 0.002 \mathrm{ml}$ of duodenal content from one of the controls; $b, 0.1 \mathrm{ml}$ of duodenal content from $\mathrm{T}$. $\mathrm{N}$.; $c, 0.1 \mathrm{ml}$ of gastric content from T. N., and $d, 0.05 \mathrm{ml}$ of gastric content from one of the controls. Incubations were performed as described previously $(9,10)$.

\section{RESULTS}

SELECTIVITY OF LIPASE ACTIVITY DETERMINATION

To discriminate between the activities of the two enzymes that you expect to find in duodenal contents, i.e., lingual lipase and pancreatic lipase, the pH optima of each enzyme was determined. Long-chain triglyceride was used as substrate, and the determinations were made in two systems including either bovine serum albumin or $\mathrm{CaCl}_{2}$. Lingual lipase had a $\mathrm{pH}$ optimum of around 6.0 both when using bovine serum albumin (Fig. 1) and $\mathrm{CaCl}_{2}$, not shown. The activity was of the same magnitude in both systems. Pancreatic lipase had a pH optimum of around 8.5 when using $\mathrm{CaCl}_{2}$ (Fig. 1) but had no activity at all when using albumin. Thus, using albumin or $\mathrm{CaCl}_{2}$ as acceptors of the released fatty acids, you could tell whether lingual or pancreatic lipase is responsible for the measured lipase activity.

\section{GASTRIC CONTENTS}

Gastric contents collected from fasting CF patients were often more acid ( $\mathrm{pH} 1.6$ to 3.2) than those obtained from fasting controls (pH 2.0 to 3.9). After feeding, gastric $\mathrm{pH}$ increased in all cases, and values around $\mathrm{pH} 5$ were usually recorded.

During fasting, lipase activities in gastric contents from both $\mathrm{CF}$ patients and controls were usually low, but in all cases, the lipase activities increased after the test meals. The lipase activity in gastric contents from four $\mathrm{CF}$ patients, when measured against tributyrin at $\mathrm{pH} 5.5$ varied within the range of 0 to 9 units $\times \mathrm{ml}^{-1}$ before feeding and 4 to 28 units $\times \mathrm{ml}^{-1}$ after feeding. The corresponding values for seven infant controls were 0 to 7 units $\times \mathrm{ml}^{-1}$ before feeding and 22 to 78 units $\times \mathrm{ml}^{-1}$ after. Similar patterns were obtained when using triolein as substrate at $\mathrm{pH} 6.0$ with albumin in the system. The values were for two CF patients 0 and 0.9 to 4.0 units $\times \mathrm{ml}^{-1}$, before and after feeding, corresponding to 0.4 to 1.5 and 2.0 to 5.2 for the controls. Gastric contents from one of the cases showed optimal lipase activity against emulsified triolein around $\mathrm{pH} 6$ (data not shown), and during hydrolysis of this substrate, there was an initial rapid release of mainly diolein and even at about $40 \%$ hydrolysis of the triglyceride diglyceride was the major partial glyceride found (Fig. 2). This correlates well with the lipid composition in duodenal contents after feeding (Fig. 3), where the triglycerides had decreased to less than $50 \%$ after $2 \mathrm{hr}$ postprandially with a corresponding increase of fatty acids and partial glycerides.

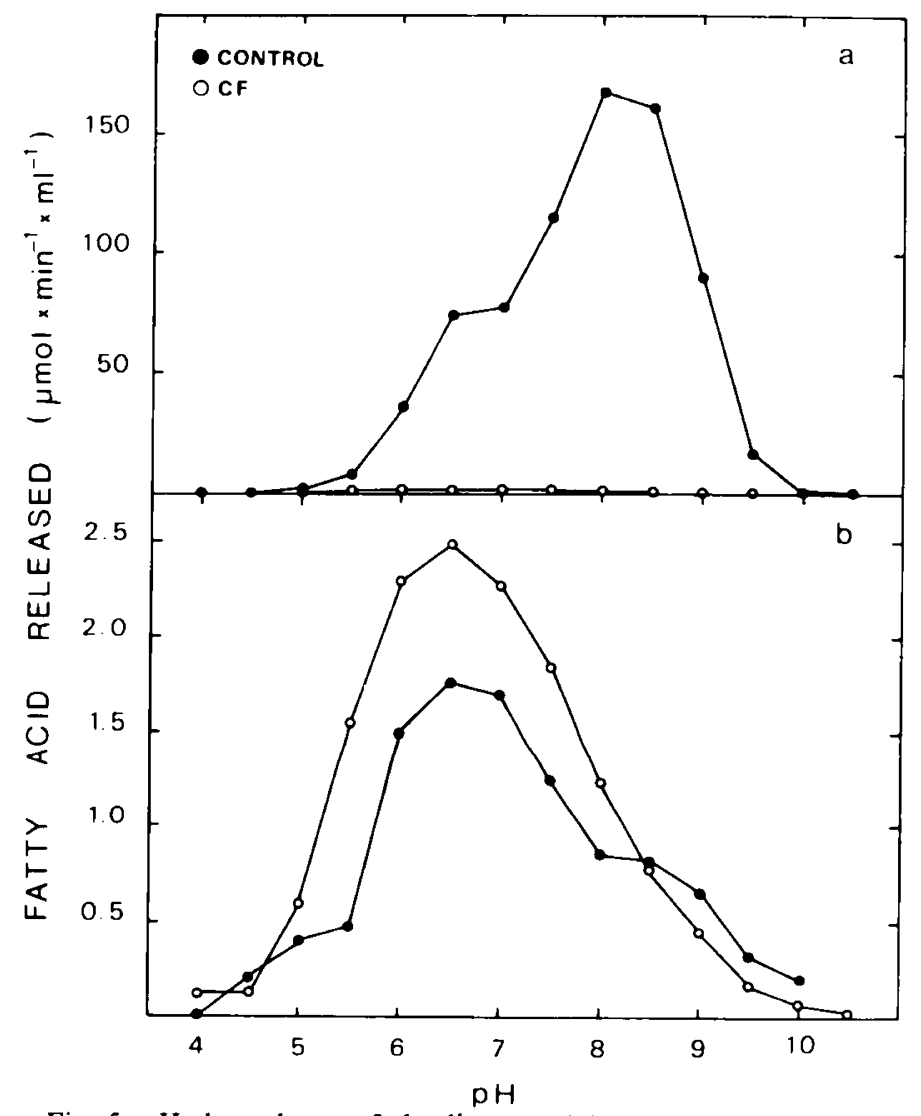

Fig. 5. $\mathrm{pH}$ dependence of the lipase activity in duodenal contents measured using long-chain triglycerides as substrate with either $8 \mathrm{mM}$ $\mathrm{CaCl}_{2}(a)$ or $2.8 \%$ bovine serum albumin $(b)$ in the system. 0 , adult control; $O$, mean values of three $C F$ patients (cases $L$. N., T. F., and N. L.). 


\section{DUODENAL CONTENTS}

Duodenal contents collected from controls were often slightly alkaline ( $\mathrm{pH} 5.9$ to 7.7 ) whereas those obtained from $\mathrm{CF}$ patients were more acidic ( $\mathrm{pH} 4.0$ to 7.0). All samples of duodenal contents obtained from controls contained high lipase and esterase activities (Table 1). During routine determination of lipase activity against tributyrin higher enzyme activity was invariably found at $\mathrm{pH} 8.0$ than at pH 5.5 (Fig. 4a).

In samples of duodenal contents from $\mathrm{CF}$ patients, both lipase and esterase activities were much lower than in controls (Table 1; Fig. 4) which is in good agreement with observations made by others (19). In contrast to the controls, lipase activities in these samples were invariably higher during assays at $\mathrm{pH} 5.5$ than at pH 8.0 (Table 1; Fig 4b). The pH-optimum of the lipase activity, measured against long-chain triglycerides as substrate, from one control was as expected around 8.5 when including $\mathrm{CaCl}_{2}$ in the system (Fig. 5a). This correlated well with the $\mathrm{pH}$ optimum for pancreatic lipase (Fig. 1). If $\mathrm{CaCl}_{2}$ was exchanged for albumin, most of the activity was lost, and the $\mathrm{pH}$ optimum was shifted to around 6.0 (Fig. $5 b$ ). The lipase activity in duodenal content from $\mathrm{CF}$ patients, on the other hand, had the same $\mathrm{pH}$-optimum with both fatty acid acceptors, i.e., around $\mathrm{pH} 6.0$ (Fig. 5) which is very close to that of the pharyngeal lipase preparation (Fig. 1) and also similar to the $\mathrm{pH}$ optimum of gastric content lipase activity (2). When incubated in the albumin-containing system, the enzyme activities of duodenal content from both control and CF patients were of about equal magnitude (Fig. $5 b$ ).

Lipase activity in duodenal contents from $\mathbf{T}$. $\mathbf{N}$. was much more resistant to acid inactivation than lipase activity obtained from controls; after $20 \mathrm{~min}$ incubation at $\mathrm{pH} 3.0$, more than $85 \%$ of initial lipase activity was still present whereas in the control virtually all lipase activity was lost during this procedure.

In spite of low intraluminal activity of both lipase and esterase in case L. N., milk lipids were extensively hydrolyzed during the test meal (Fig. 3). Fat balance studies were performed on two cases (T. N. and L. N.), and the absorption coefficients were 47 and $41 \%$, respectively.

\section{DISCUSSION}

Only a few CF patients secrete sufficient amounts of digestive enzymes to maintain normal growth without enzyme supplementation (11). The six CF patients studied in this report had characteristic signs of exocrine pancreatic insufficiency and were taking exogenous pancreatic enzymes with their meals. Nevertheless, during fat balance studies without pancreatic enzyme preparations, two of the patients absorbed more than $40 \%$ of the dietary lipids. Similar results have been reported by others $(18,23)$. We have previously found that gastric contents collected during fasting often contain little or no lipase activity, but this enzyme activity is always present in samples of gastric contents obtained after feeding (9), and in this study, identical observations were made in CF patients. Thus, the present study clearly shows that gastric contents from CF patients contain lipase activities with properties that are similar to those found in healthy subjects.

Duodenal contents from CF patients contained low but significant lipase activities (Table 1). To our knowledge, the properties of these lipase activities have not been studied in detail previously. We found that there were great similarities between the lipase activity in gastric and duodenal contents from CF patients and lingual lipase prepared from rat tongue (compare Figs. 1 and 5). It is also similar to the characteristics of the lipase activity in gastric contents from patients with pyloric stenosis reported previously (2). These observations indicate that a lipase, presumably lingual lipase, passes through pylorus and is present in an active form in duodenum. Due to the pancreatic insufficiency in $C F$, intraluminal proteolytic activity is low, and thus the lipase is not rapidly destroyed (5), and furthermore, the $\mathrm{pH}$ in the duodenum is close to the $\mathrm{pH}$ optimum of lingual lipase. It has been reported that bile salts inhibit the activity of lingual lipase (13), but the bile salt concentration prevailing in the duodenum of CF patients is too low to give any significant inhibition (16). Thus, further hydrolysis may take place in the intestine. This is clearly shown in Fig. 3 where more than $50 \%$ of milk triglycerides had been hydrolyzed within $2 \mathrm{hr}$. This study supports the hypothesis that lingual lipase is responsible for some if not all of the hydrolysis of dietary triglycerides that do take place in the CF patients receiving no pancreatic supplementation.

\section{REFERENCES AND NOTES}

1. Bläckberg, L., Hernell, O., Bengtsson, G., and Olivecrona, T.: Colipase enhances hydrolysis of dietary triglycerides in the absence of bile salts. J. Clin. Invest., 64: 1303 (1979).

2. Bläckberg, L., Hernell, O., Fredrikzon, B., and Ȧkerblom, H. K.: On the source of lipase activity in gastric contents. Acta Paediatr. Scand., 66: 473 (1977).

3. Borgström, B., and Erlanson, C.: Pancreatic lipase and co-lipase. Interactions and effects of bile salts and other detergents. Eur. J. Biochem., 37: 60 (1973).

4. Borgström, B., and Erlanson, C.: Interactions of serum albumin and other proteins with porcine pancreatic lipase. Gastroenterology, 75: 382 (1978).

5. Cohen, M., Morgan, T. G. H., and Hofmann, A. F.: Lipolytic activity of human gastric and duodenal juice against medium and long chain triglycerides. Gastroenterology, 60: 1 (1971).

6. di Sant'Agnese, P. A.: Fibrocystic disease of the pancreas with normal or partial pancreatic function. Pediatrics, 15: 683 (1955).

7. Erlanson, C.:p-Nitrophenyl acetate as a substrate for carboxylester hydrolase in pancreatic juice and intestinal content. Scand. J. Gastroenterol., 5: 333 (1970).

8. Erlanson, C.: Purification, properties, and substrate specificity of a carboxylesterase in pancreatic juice. Scand. J. Gastroenterol., 10: 401 (1975).

9. Fredrikzon B., and Hernell, $O$.: Role of feeding on lipase activity in gastric contents. Acta Paediatr. Scand., 66: 479 (1977).

10. Fredrikzon, B., and Olivecrona, T.: Decrease of lipase and esterase activities in intestinal contents of newborn infants during test meals. Pediatr. Res., 12: 63 ! (1978).

11. Hadorn, B., Johansen, P. G., and Anderson, C. M.: Pancreozymin secretin test of exocrine pancreatic function in cystic fibrosis and the significance of the results for the pathogenesis of the disease. Can. Med. Assoc. J., 98: 377 (1968).

12. Hamosh, M.: A review. Fat digestion in the newborn: role of lingual lipase and preduodenal digestion. Pediatr. Res., 13: 615 (1979).

13. Hamosh, M., and Burns, W. A. Lipolytic activity of human lingual glands (Ebner). Lab. Invest. 37: 603 (1977)

14. Hamosh, M., Klaeveman, H. L., Wolf, R. O., and Scow, R. O.: Pharyngeal lipase and digestion of dietary triglyceride in man. J. Clin. Invest., 55: 908 (1975).

15. Hamosh, M. Sivasubramanian, K. N., Salzman-Mann, C., and Hamosh, P.: Fat digestion in the stomach of premature infants. J. Pediatr.. 93: 674 (1978).

16. Harries, J. T., Muller, D. P. R., McCollum, J. P. K., Lipson, A., Roma, E., and Norman, A. P.: Intestinal bile salts in cystic fibrosis. Arch. Dis. Child., 54: 19 (1979).

17. Johnston, J. M.: Mechanism of fat absorption. In: C. F. Code, W. Heidel: Handbook of Physiology. Section 6, Vol. III, p. 1353 (The Williams \& Wilkins Co., Baltimore, MD, 1967)

18. Lapey, A., Kattwinkel, J., and di Sant'Agnese, P. A.: Steatorrhea and azotorrhea and their relation to growth and nutrition in adolescents and young adults with cystic fibrosis. J. Pediatr., 84328 (1974).

19. McCollum, J. P. K., Muller, D. P. R., and Harries, J. T.: Test meal for assessing intraluminal phase of absorption in childhood. Arch. Dis. Child., 52: 887 (1977).

20. Muller, D. P. R., McCollum, J. P. K., Trompeter, R. S., and Harries, J. T. Studies on the mechanism of fat absorption in congenital isolated lipase deficiency. Gut, 16: 838 (1975).

21. Nelson, J. H., Jensen, R. G., and Pitas, R. E: Pregastric esterase and other oral lipases-a revicw. J. Diary Sci., 60: 327 (1976).

22. Olivecrona, T., Billström, A., Fredrikzon, B., Johnson, O., and Samuelson, G. Gastric lipolysis of human milk lipids in infants with pyloric stenosis. Acta Paediatr. Scand., 62: 520 (1973).

23. Ross, C. A. C., and Sammons, H. G.: Non-pancreatic lipase in children with pancreatic fibrosis. Arch. Dis. Child., 30: 428 (1955).

24. van de Kamer, J. H., ten Bokkel Huinink, H., and Weijers, H. A.: Rapid method for determination of fat in faeces. J. Biol. Chem., I77: 347 (1949).

25. Verger, R., De Haas, G. H., Sarda, L., and Desnuelle, P.: Purification from porcine pancreas of two molecular species with lipase activity. Biochim. Biophys. Acta, /88: 272 (1969).

26. Gum arabic, bovine serum albumin and tributyrin were obtained from Sigma Chemical Company, St. Louis, MO.

27. Tri $\left(9,10 n-{ }^{3} \mathrm{H}\right)$-oleylglycerol was purchased from New England Nuclear Chemicals GmbH, Dreieichenhain, Germany.

28. This study was approved by the Committee on Research involving Human Subjects of the Medical Faculty, University of Umea.

29. Informed consent was obtained from the parents of each patient.

30. Requests for reprints should be addressed to: Dr. Bo Fredrikzon, Department of Pediatrics, University of Umeả, S-901 85 Umeả, Sweden.

31. This research was supported by the Swedish Medical Research Council (19X05708), The Swedish Nutrition Foundation. The Swedish Baby Food Industry Fund for Nutritional Research, AB Findus. The Swedish Society of Medical Sciences, and the Medical Faculty, University of Umea.

32. Received for publication December 5, 1979

33. Acrepted for publication April 8, 1980 